\title{
Development of a Super Ductile Diecast Al-Mg-Si Alloy
}

S. Ji ${ }^{*}$, D. Watson ${ }^{1,2}$, Z. Fan ${ }^{1}$ and M. White ${ }^{2}$

1-The EPSRC Centre - LiME, BCAST, Brunel University, Uxbridge UB8 3PH, United Kingdom

2- Engineering Centre, Jaguar Cars Ltd, Abbey Road, Coventry, CV34 4LF, United Kingdom

\begin{abstract}
The super ductile diecast aluminium alloys have been developed particularly for application in automotive body structure. On the basis of the reviewing aluminium alloys currently available, the requirement of diecast aluminium alloys is summarized and the Al-Mg-Si system is focused in the development. The effect of various alloying elements on the microstructure and the mechanical properties, such as yield strength, ultimate tensile strength and elongation is assessed. The optimized composition of the super ductile Al-Mg-Si alloy has been found to be at 5.0-5.5wt-\% Mg, $1.5-2.0 \mathrm{wt}-\% \mathrm{Si}, 0.5-0.7 \mathrm{wt}-\% \mathrm{Mn}, 0.15-$ $0.2 \mathrm{wt}-\% \mathrm{Ti}$ with $\mathrm{Fe}<0.25 \mathrm{wt}-\%$ for the best combination of strength and ductility, which shows $150 \mathrm{MPa}$ of yield strength, $300 \mathrm{MPa}$ of ultimate tensile strength, and $15 \%$ of elongation under as-cast condition. The paint baking hardenability of the optimized alloy is found to be insignificant. Less than a $10 \%$ increase in the yield strength was achieved, with a slight decrease in the elongation after aging at $180^{\circ} \mathrm{C}$ for $30 \mathrm{~min}$, which is a simulated process of paint baking. $\mathrm{Cu}$ is found to slightly increase the yield strength under the as-cast condition and after the heat treatment, but with a significant reduction in the ductility. Therefore, $\mathrm{Cu}$ should be limited in the super ductile aluminium alloy. The microstructure of diecast aluminium alloys at the optimized composition consists of the primary $\alpha$-Al phase, the $\alpha$-AlFeMnSi intermetallics and the $\mathrm{Al}-\mathrm{Mg}_{2} \mathrm{Si}$ eutectics. There are two types of primary $\alpha$-Al phase: dendritic or fragmented dendritic $\alpha-\mathrm{Al}$ phase solidified in the shot sleeve and globular $\alpha$-Al particles solidified in the die cavity. The $\alpha-\mathrm{AlFeMnSi}$ intermetallics is in the form of compact morphology and with a size of less than $3 \mu \mathrm{m}$. The eutectic cells are at size of $10 \mu \mathrm{m}$ with a typical lamellar morphology of $\alpha-\mathrm{Al}$ phase and $\mathrm{Mg}_{2} \mathrm{Si}$ phase.
\end{abstract}

Key words: aluminium alloys, die casting, super ductility, solidification, microstructure.

\section{Introduction}

In the manufacture of transport, weight reduction through the use of lightweight materials remains a very successful and simple means of improving fuel economy and reducing harmful emissions [1]. Increases in aluminium alloys for automotive applications provide significant opportunities for weight reduction and therefore real scope to achieve the environmental goals [2,3]. The automotive industry has used a range of aluminium components in power trains and chassis including transmission housings, cylinder heads, inlet manifolds, engine sumps, wheels, as well as for decorative trim items [4]. An increasing trend in replacing steel parts with lighter aluminium ones has seen aluminium alloys being used extensively in other automotive areas. One of the significant progresses in most recent years has been in the application of aluminium-intensive car body structure $[5,6]$.

In the automotive body structure, both wrought and cast aluminium alloys are essential in frame-space design and monocoque design of aluminium-intensive passenger cars [1,7]. The currently available wrought alloys are listed in Table $1[8,9]$. The mechanical properties of alloys are 124 to $240 \mathrm{MPa}$ of yield strength, $220-317 \mathrm{MPa}$ of ultimate tensile strength, and $10-30 \%$ of elongation. Some alloys that are usually used for external surfacing exhibit excellent paint baking hardenability. The yield strength increases by up to $60 \%$ after paint baking. In order to maximize the benefits of aluminium-intensive car body structure, the die castings need to have comparable mechanical properties with the components made with aluminium sheet. However, the mechanical properties of currently available diecast alloys, as listed in Table $2[10,11]$, are not competitive and cannot satisfy the industrial requirement. In particular, the ductility is not sufficient in manufacturing and in application. To increase the strength of castings, the wall thickness needs to be increased for the available alloys. However, several extra manufacturing steps and extra tools have to be added in production to make quality products. These still cannot avoid the insufficiency of ductility and also are not preferred in industry due to the increase of casting weight and processing costs. Therefore, the cast alloy needs to be specially developed for car body structure and similar applications.

\footnotetext{
*Tel: +44-1895-266663, Email: shouxun.ji@brunel.ac.uk
} 
This paper attempts to describe the development of a diecast aluminium alloy that can satisfy the requirement of mechanical properties, in particular ductility for application in automotive body structure. On the basis of reviewing the cast alloys currently available in industry, the Al-Mg-Si system was focused in the investigation of the effect of various alloying elements on the mechanical properties, which resulted in an optimised alloy composition. Because the paint baking hardening has been widely used in automobile industry for property enhancement of aluminium alloys, an investigation of the effect of a simulated ageing process at $180^{\circ} \mathrm{C}$ on the mechanical properties of casting was also carried out. The solidification behaviour, phase formation and the correlation between microstructure and the mechanical properties of the diecast alloy are discussed in detail.

\section{The requirement for cast alloys in automotive body structure}

Currently, there is still a lack of clear requirement for the cast alloys used in automotive body structure, partially because of the insufficient experience in the application of aluminium automotive body. However, we can get indication from the extensively used wrought alloys in the body structure. The basic requirements for the cast alloys suitable for automotive body structure are summarized as follows:

(1) Die-castable at typical wall thickness of 2 to $4 \mathrm{~mm}$ with low level of porosity,

(2) Excellent ductility with breaking elongation at least $15 \%$ under as-cast condition,

(3) A level of 150MPa of yield strength and $300 \mathrm{MPa}$ of ultimate tensile strength of die casting under as-cast condition,

(4) Appropriate corrosion resistant,

(5) Potential of paint baking hardening at $180^{\circ} \mathrm{C}$ for 30 minutes that is commonly used in industry,

(6) Compatible with wrought aluminium alloys used as sheet/extruded parts in automotive body structure. This is particularly important for the possible closed loop recycling of materials in the future.

Of these requirements, the properties and cost are two major concerns. The requirements of the properties include the mechanical performance and the corrosion resistance. The cost control includes the use of die castings that can easily achieve massive production and hence lowering the component cost. Meanwhile the compatibility with wrought alloys can reduce the recycle cost at the end life of vehicles.

The properties of a diecast alloy depend firstly on its composition, although the effect of the processing during its production is also very important. Each alloying element affects the alloy properties both independently and interactively [12]. Currently, the diecast aluminium alloys include $\mathrm{Al}-\mathrm{Si}-\mathrm{Cu}, \mathrm{Al}-\mathrm{Si}$ and $\mathrm{Al}-\mathrm{Mg}-\mathrm{Si}$ and $\mathrm{Al}-\mathrm{Mg}$ alloys, as shown in Table 2. Al-Si-Cu and Al-Si alloys are the most popular diecast alloys that offer a good combination of strength, castability and processability, but less ductility. Al-Mg-Si alloy can provide a better ductility, but still is not sufficient for car body structure. The specification of available Al-Mg-Si diecast alloys varies in different countries. Some of them are listed in Table 3 with the grade designation and composition [13,14]. The alloys provide mechanical properties at $90-120 \mathrm{MPa}$ of yield strength, 170-280MPa of ultimate tensile strength and 3-5\% of elongation. To meet the requirement mentioned above for the automotive body structure, the ductility needs to be improved significantly, while both the yield strength and the ultimate tensile strength should be further improved. On the other aspects, high level of magnesium in aluminium alloys can easily cause oxidization during processing and extra care needs to be taken for $\mathrm{Mg}$ content in the alloy, although it can be minimized by adding a small amount of beryllium.

In consideration of the wrought aluminium alloys that have been extensively used in automotive body structure; the mainly alloying elements are $\mathrm{Mg}, \mathrm{Si}$ and $\mathrm{Cu}$, as seen in Table 1. Therefore it is advantage to use Al-Mg-Si alloy for automotive body structure if its ductility can be improved under as-cast condition. This can offer a possibility to achieve closed loop recycling at the end life of body structure, which is beneficial for the environment and cost-saving [9]. In recent years, trials have been made to add rare earth elements or scandium to Al-Mg-Si alloys in order to improve the mechanical properties [15, 16]. However, the utilization of costly elements is not preferred in industry. Therefore, the development of new Al-Mg-Si diecast alloy should focus on the composition optimization with less level of the costly elements.

\section{Experimental}

Pure aluminium, pure magnesium, Al-15wt- $\% \mathrm{Si}, \mathrm{Al}-20 \mathrm{wt}-\% \mathrm{Mn}$, and $\mathrm{Al}-10 \mathrm{wt}-\% \mathrm{Ti}$ master alloy ingots were used as base materials. Each of them was supplied at a specified composition with commercial purity. 
During experiments, each element was weighed to a specified ratio with additional amounts for burning loss during melting. The melt of $10 \mathrm{~kg}$ was prepared each time in a clay-graphite crucible using an electric resistance furnace. During melting, the temperature of the melting furnace was measured at $710 \pm 10^{\circ} \mathrm{C}$. The ingots containing $\mathrm{Al}, \mathrm{Si}$ and $\mathrm{Mn}$ elements were loaded into the crucible and melted first. Then $\mathrm{Mg}$ ingot that had been preheated to $200^{\circ} \mathrm{C}$ was carefully added into the completely melted solution. After 30 minutes of homogenisation, the melt was subjected to degassing and fluxing using $\mathrm{N}_{2}$ and commercial fluxes. The $\mathrm{N}_{2}$ degassing usually lasted 3 minutes and the granular flux covered the top surface of the melt during degassing. The Al-10wt-\% Ti master alloy that had been preheated to $500^{\circ} \mathrm{C}$ was finally added into the melt after degassing. The melt was subsequently held in the furnace for about 20 minutes for homogenisation before taking sample for composition measurement.

A $\phi 40 \times 60 \mathrm{~mm}$ cylindrical casting made by a steel mould was utilized for composition analysis. The casting was cut across the diameter at $15 \mathrm{~mm}$ from the bottom and ground down to 800 grid sand paper. The composition of each alloy was obtained from an optical mass spectroscopy, in which at least five spark analyses were performed and the average was taken as the chemical composition of alloy.

After composition analysis and skimming, the melt was manually dosed and subsequently released into the shot sleeve of a $2800 \mathrm{kN}$ HPDC machine for final casting. The pouring temperature was measured by a Ktype thermocouple, usually at $650^{\circ} \mathrm{C}$ unless specified in relative experimental results. A specially designed die was used to cast samples for tensile tests, which allowed casting four ASTM standard samples with $6.4 \mathrm{~mm}$ in diameter for each shot. The main dimensions and diagram of die castings with overflow and biscuit are shown in Figure 1. The die temperature was controlled at $210^{\circ} \mathrm{C}$ in all shots. All castings were left on the shop floor for at least 24 hours before testing the mechanical properties.

The age hardening characteristics were studied by heating the samples to $180^{\circ} \mathrm{C}$ and held for different periods of times. The as-cast tensile samples were heat treated in an electric resistance furnace that was preheated to a given temperature for at least one hour in advance. The temperature inside the chamber was monitored by a separate thermal couple with a variation of $\pm 3{ }^{\circ} \mathrm{C}$ during heat treatment.

The tensile tests were conducted following ASTM standard B557, using an Instron 5500 Universal Electromechanical Testing Systems equipped with Bluehill software and a $\pm 50 \mathrm{kN}$ load cell. All tensile tests were performed at an ambient temperature $\left(\sim 25^{\circ} \mathrm{C}\right)$. The gauge length of the extensometer was $25 \mathrm{~mm}$ and the ramp rate for extension was $2 \mathrm{~mm} / \mathrm{min}$. Each set of data reported is based on the properties obtained from 10 to 30 samples without showing obvious casting defects on the fracture surfaces.

The microstructure of each alloy was examined using a Zeiss optical microscope with quantitative metallography, and a Zeiss SUPRA 35VP scanning electron microscope (SEM), equipped with energy dispersive spectroscopy (EDS). All metallographic samples were prepared by the standard technique. Quantitive metallography was conducted using an AxioVision 4.3 Quantimet digital image analysis system. Usually five different fields of views were analysed for each specimen and the average was taken as the measured value. The quantitative SEM/EDS analysis was performed under the $20 \mathrm{kV}$ accelerating voltage with calibration being carried out before each session. To minimise the influence from the interaction volume, five point analyses on selected particles or areas were conducted for each phase and the average was taken as the measurement.

\section{Results \\ 4.1 Effect of alloying elements on mechanical properties \\ 4.1.1 Effect of $\mathrm{Mg}$ and $\mathrm{Si}$}

Figure 2 shows the phase diagrams at Al-rich side for $\mathrm{Al}-\mathrm{Mg}_{2} \mathrm{Si}$ pseudo-binary system and $\mathrm{Al}-\mathrm{Mg}-\mathrm{Si}$ ternary system on the cross section of $98 \mathrm{Al} 2 \mathrm{Si}[17,18]$. The maximum solid solubility of $\mathrm{Mg}$ in $\mathrm{Al}$ is at $17.4 \mathrm{wt}-\%$ under equilibrium conditions. The $\mathrm{Mg}$ content usually does not exceed 5\% in wrought alloys and does not exceed $10 \%$ in cast alloys. The Al-Mg alloy is one of the best aluminium alloys that are capable of providing the good corrosion resistance in a moist environment and in seawater. Silicon has a solubility of $1.65 \mathrm{wt}-\%$ in aluminium. Silicon can prevent the formation of hot tearing defects and improve the castability of aluminium alloys. Magnesium and silicon can form $\mathrm{Mg}_{2} \mathrm{Si}$ intermetallic compound, which has a maximum solubility in $\mathrm{Al}$ at $1.85 \mathrm{wt}-\%$ under equilibrium condition. Magnesium and silicon content in the alloy should be chosen at or near this point to maximize the solubility to enhance solution 
strengthening in as-cast state. As shown in Figure $2 \mathrm{~b}$, although $\mathrm{Mg}$ content can be varied in a relatively large range, it is preferred in a range of $5-8 \mathrm{wt}-\%$ in $\mathrm{Al}-\mathrm{Mg}-\mathrm{Si}$ based alloy to have a relatively narrow solidification range that is essential for diecast alloy.

Figure 3 shows the experimental results of the effect of $\mathrm{Mg}$ and $\mathrm{Si}$ on the yield strength, the tensile strength and the elongation of the diecast alloys, in which other elements were fixed at $0.6 \mathrm{wt}-\% \mathrm{Mn}, 0.2 \mathrm{wt}-$ $\% \mathrm{Ti}$ and $0.25 \mathrm{wt}-\% \mathrm{Fe}$. It is seen that both $\mathrm{Mg}$ and $\mathrm{Si}$ resulted in a significant increase of the yield strength and the ultimate tensile strength, but a significant decrease of the elongation. When $\mathrm{Mg}$ content increased from $4.5 \mathrm{wt}-\%$ to $8 \mathrm{wt}-\%$, the yield strength increased from a level of $140 \mathrm{MPa}$ to $170 \mathrm{MPa}$, and the ultimate tensile strength increased from a level of $260 \mathrm{MPa}$ to $340 \mathrm{MPa}$, but the elongation decreased significantly from a level of $18 \%$ to $10 \%$. When the $\mathrm{Mg}$ was at a level of 5-6wt-\% and Si content increased from 1wt-\% to $2.5 \mathrm{wt}-\%$, the yield strength increased from a level of $125 \mathrm{MPa}$ to $160 \mathrm{MPa}$, and the ultimate tensile strength increased from a level of $270 \mathrm{MPa}$ to $310 \mathrm{MPa}$, but the elongation decreased from a level of $18 \%$ to $14 \%$. The results indicated that $\mathrm{Mg}$ can enhance the mechanical properties of the diecast alloys more significantly than $\mathrm{Si}$ can in as-cast state. The results also implied that a higher level of $\mathrm{Mg}$ in the alloy can provide more strengthening in solid solution. It was observed that Si could significantly improve the castability and reduce hot tearing defects in the alloy. The addition of Si over $1.5 \%$ is essential to produce castings with reduced hot tearing defects.

\subsubsection{Effect of Ti}

Titanium is a popular element used in wrought aluminium alloys as grain refiner in both as-cast state and heat-treated state. The experimental results shown in Figure 4 confirm that Ti could significantly increase the elongation of the diecast $\mathrm{Al}-\mathrm{Mg}-\mathrm{Si}$ alloy at a very low level. The elongation was at a level of $11 \%$ at $0.015 \mathrm{wt}-\% \mathrm{Ti}$ and it increased to $18 \%$ at $0.15 \mathrm{wt}-\% \mathrm{Ti}$. It is more significant because Ti could also increase the yield strength and the ultimate tensile strength. The increase of strength was up to $10 \%$ when Ti was at a level of $0.2 \mathrm{wt}-\%$. Therefore, $\mathrm{Ti}$ is an essential element for super ductile diecast aluminium alloys.

\subsubsection{Effect of $\mathrm{Cu}$}

Copper is usually used to enhance paint baking hardenability in wrought alloys. Figure 5 shows the relationship between $\mathrm{Cu}$ content and the strength and elongation of the die castings. It is seen that $\mathrm{Cu}$ slightly increased the yield strength, but significantly decreased the elongation and the ultimate tensile strength of diecast $\mathrm{Al}-\mathrm{Mg}-\mathrm{Si}$ alloy in as-cast state. The main reasons might be that $\mathrm{Cu}$ increases the tendency of hot tearing in the diecast alloys, which not only reduces the strength and the elongation, but also varies the process conditions.

\subsubsection{Effect of Fe and Mn}

Iron is usually considered a detrimental impurity in diecast aluminium alloys because it is unavoidable and easy to exceed the limits during melting and casting $[19,20]$. The results shown in Figure 6 confirm that the yield strength, the ultimate tensile strength and the elongation decreased noticeably with the increase of Fe content. The decrease was more significant for the elongation. This confirms that Fe should be limited in the alloy to satisfy the requirement of super ductility. Mn has been found to have no significant effect on the mechanical properties of $\mathrm{Al}-\mathrm{Mg}-\mathrm{Si}$ alloy in the experimental range. However, $\mathrm{Mn}$ is an effective element to prevent die soldering in the die casting process, especially when $\mathrm{Fe}$ is limited at a low level. During experiments, the casting release became difficult when $\mathrm{Mn}$ was below $0.4 \mathrm{wt}-\%$ and $\mathrm{Fe}$ was at the same level of $0.25 \mathrm{wt}-\%$. One important role for the existence of $\mathrm{Mn}$ in diecast aluminium alloys is that $\mathrm{Mn}$ can alter the morphology of $\mathrm{Fe}$-bearing intermetallics by promoting the formation of compact $\alpha$-AlFeMnSi intermetallics and suppressing the formation of needle/plate $\beta$-AlFeSi intermetallics, which is beneficial for the mechanical properties, especially for the ductility of the diecast alloys.

Based on the experimental results, the optimized composition of the super ductile Al-Mg-Si alloy has been selected at a level of $5-5.5 \mathrm{wt}-\% \mathrm{Mg}, 1.5-2.0 \mathrm{wt}-\% \mathrm{Si}, 0.5-0.7 \mathrm{wt}-\% \mathrm{Mn}$ and $0.15-0.2 \mathrm{wt}-\%$ Ti. The other elements are impurities and are limited at low level. In particular, Fe should be less than $0.25 \mathrm{wt}-\%$. The mechanical properties of the alloy at the optimized composition are shown in Figure 7. The results confirmed that the yield strength of $150 \mathrm{MPa}$, the ultimate tensile strength of $300 \mathrm{MPa}$, and the elongation of $15 \%$ were achievable in the designed castings. The value of the mechanical properties can satisfy the requirements for automotive body structure according to the standard described above. 


\subsection{The effect of ageing}

Paint baking hardening is one of significant benefits for wrought alloys. Although the paint baking cycle in industry varies from each other in factories, the paint is usually baked at a temperature around $180^{\circ} \mathrm{C}$. In this work, ageing has been carried out at a fixed temperature of $180^{\circ} \mathrm{C}$ to examine the properties at different times. Figure 8 shows the effect of ageing time on the mechanical properties of castings. While the ultimate tensile strength showed no significant variation, the yield strength slightly increased and the elongation decreased with the prolonged ageing time at $180^{\circ} \mathrm{C}$. With regards to the response at 30 minutes, which is often used in paint baking process, the increase of the yield strength and the decrease of the elongation were less than $10 \%$, respectively. This indicates that the paint baking hardening of diecast Al$\mathrm{Mg}-\mathrm{Si}$ alloy is insignificant under as-cast condition.

In order to enhance the response of paint baking, a further experiment was carried out to study the effect of $\mathrm{Cu}$ on the mechanical properties after ageing. The results are shown in Figure 9, in which the yield strength and the ultimate tensile strength increased noticeably with the increase of ageing time, but the elongation decreased significantly with the increase of ageing time. In particular, when $\mathrm{Cu}$ was at $0.39 \mathrm{wt}-$ $\%$, the elongation was so low under both as-cast and aged conditions that the ductility was as low as $6 \%$ or lower, which could not satisfy the product requirement. In comparing the results in Figures 8 and 9; alloys with $\mathrm{Cu}$ provide a higher strength, but a lower elongation during the same ageing time.

\subsection{The microstructural characteristics of the diecast alloy}

The typical microstructure of the as-cast Al-Mg-Si alloy with $5 \mathrm{wt}-\% \mathrm{Mg}, 1.5 \mathrm{wt}-\% \mathrm{Si}, 0.6 \mathrm{wt}-\% \mathrm{Mn}, 0.2 \mathrm{wt}-$ $\% \mathrm{Ti}$ and $0.25 \mathrm{wt}-\% \mathrm{Fe}$ is shown in Figure 10. The microstructure consists of dendrites or fragmented dendrites of primary $\alpha$-Al phase, globular primary $\alpha$ - $\mathrm{Al}$ phase and eutectics phase of $\alpha-\mathrm{Al}$ and $\mathrm{Mg}_{2} \mathrm{Si}$. The primary dendrites and fragmented dendrites were relatively coarse (Fig. 10a). The average size was at a level of $43 \mu \mathrm{m}$, although the sizes varied from few micrometers to several hundred micrometers. They were formed in the shot sleeve of the die caster. The volume fraction of the dendritic microstructure depended on the pouring temperature and the time of the melt in the shot sleeve. The lower pouring temperature and the longer rest time for the melt resting in the shot sleeve would increase the larger amount of dendrites in the microstructure. Some dendrites could be fragmented partially or completely when they passed through the ingate of casting, where high speed and high shear were created within the melt. The fragmented dendrites exhibited globular morphology (Fig. 10b\&c). In the as-cast microstructure, the fine spheroidal particles were formed in the die cavity. The mean particle size was at a level of $7.5 \mu \mathrm{m}$ (Fig. 10c). During die filling, the melt was experiencing a high shear whilst passing through the ingate. The heat transfer was enhanced between the melt and the low temperature die block, and therefore the melt solidified under a high cooling rate. The relatively large undercooling could be created in the melt, which resulted in an enhanced nucleation during solidification and finer microstructure in the casting because the solidification process inside the die cavity finished before the primary phase grew up in dendrites. As a result, the globular morphology of the primary $\alpha$-Al phase was formed inside the die cavity. The eutectics were also formed in the eutectic solidification inside the die cavity. The detailed microstructure of eutectics is shown in Figure 11. The lamellar eutectics were usually located between the primary particles. The EDS analysis has confirmed the eutectics consisted of $\alpha-\mathrm{Al}$ phase and $\mathrm{Mg}_{2} \mathrm{Si}$ phase. The size of the eutectic cells was at a level of $10 \mu \mathrm{m}$. The $\mathrm{Mg}_{2} \mathrm{Si}$ was the dominant phase in the as-cast state throughout the range of tested compositions. The lamellar $\mathrm{Mg}_{2} \mathrm{Si}$ in the eutectics was less than $0.2 \mu \mathrm{m}$ thick. The amounts of $\mathrm{Mg}_{2} \mathrm{Si}$ phases depended on the level of $\mathrm{Mg}$ and $\mathrm{Si}$ in the alloy. The primary $\mathrm{Mg}_{2} \mathrm{Si}$ phase was not found in the developed alloy.

Also shown in Figure 11, the tiny Fe-rich intermetallic particles were found in the alloy. The intermetallic compounds were located at the boundaries of primary particles or between the eutectic cells and the primary particles. The morphology of the intermetallic phase exhibited individual particles at a size about $3 \mu \mathrm{m}$. The EDS analysis shown in Figure 11b confirmed that the intermetallic compounds contained $\mathrm{Al}$, $\mathrm{Mn}, \mathrm{Fe}$ and $\mathrm{Si}$. The quantitively measured composition of the intermetallic phase is $5 \pm 0.45 \mathrm{at}-\% \mathrm{Si}$, $13 \pm 1.55 \mathrm{at}-\% \mathrm{Fe}, 7.4 \pm 1.66$ at- $\% \mathrm{Mn}$, and $75 \pm 0.88$ at- $\% \mathrm{Al}$, which corresponds to $\mathrm{Al}_{30}(\mathrm{Fe}, \mathrm{Mn})_{8} \mathrm{Si}_{2}$. Therefore, the results confirmed that the intermetallic phase was similar to the $\alpha-\mathrm{Al}_{15}(\mathrm{Fe}, \mathrm{Mn})_{3} \mathrm{Si}_{2}$. It needs to be noted that the measured $\mathrm{Mg}$ in the EDS analysis was from the $\mathrm{Al}$ matrix other than the particles themselves because the size of analysis spot from the instrument is larger than the intermetallic particle size. 
In order to verify the presence of the elements in the identified phase in the examined alloy, series of intensity maps were performed for the elements $\mathrm{Al}, \mathrm{Mg}, \mathrm{Si}, \mathrm{Fe}, \mathrm{Mn}$ and Ti at $20 \mathrm{kV}, 185 \mathrm{nA}, 5 \mathrm{~nm}$ step size and a counting time of $15 \mathrm{~ms}$ per step. The results are shown in Figure 12 with one backscattered SEM micrograph for the analysed area. The presence of $\mathrm{Al}$ was evidently highest in the primary $\alpha$-Al phase. The presence of $\mathrm{Mg}$ and $\mathrm{Si}$ were at their maximum levels on the eutectic cells. The presence of $\mathrm{Fe}$ was at its maximum level in intermetallics. The presence of $\mathrm{Mn}$ and $\mathrm{Ti}$ were hardly identified in the measurement results. By examining the concentration of $\mathrm{Mg}$ on the field of intermetallics presence, there were some overlaps and it was therefore hard to identify whether the intermetallics contained magnesium.

\section{Discussion}

\subsection{Solidification behaviour}

In the $\mathrm{Al}-\mathrm{Mg}-\mathrm{Si}$ alloy with experimental compositions, the solidification process is critical for the formation of microstructure in the castings. The solidification process can be basically divided into three stages, during which the primary $\alpha-\mathrm{Al}$ phase, Fe-bearing intermetallic phase and the eutectic $\mathrm{Al}+\mathrm{Mg}_{2} \mathrm{Si}$ phase are formed sequentially from the melt.

With the decrease of melt temperature, $\alpha-\mathrm{Al}$ is the first solid phase formed. Once the melt is loaded into the shot sleeve, the low temperature of the shot sleeve will chill the melt immediately to a temperature below its liquidus and result in solidification. The situation is somehow similar to gravity casting. Therefore, the solidification follows conventional approach to create dendritic microstructure. However, the solidification in the shot sleeve is terminated when the piston moves forward to push the alloy into the die cavity. At that moment, the mixture of solid and liquid is pushed forward slowly at the initial stage and quickly at the end stage. Before filling into the die cavity, the melt needs to pass the ingate (Fig. 1) where the melt will experience a high shear and high velocity. During this process, the solid dendrites in the melt can be fragmented partially or completely. When the melt fills the die cavity under a high velocity, the temperature within the melt is uniformed and no superheat exists in the remnant liquid. The heat transfer between the melt and the die block is also enhanced under pressure. The solidification inside the die cavity is under a high cooling rate, during which the heterogeneous nucleation is enhanced and therefore the primary $\alpha$-Al phase cannot grow up to a full dendritic morphology before the completion of solidification. Consequently, the primary $\alpha-\mathrm{Al}$ phase formed in the die cavity is much smaller than that formed in the shot sleeve (Figure 10). Two types of primary $\alpha$-Al phase are easily identified by the morphology and size. In the die casting process, the pouring temperature, the resting time in the shot sleeve, and the temperature of shot sleeve and die block are important factors to affect the formation of the primary $\alpha$-Al phase.

With the progress of solidification, the precipitation of $\alpha-\mathrm{Al}$ phase consumes a large amount of $\mathrm{Al}$ in the melt and thus the solute is enriched in the remnant liquid. The enrichment of $\mathrm{Fe}, \mathrm{Mn}$ and $\mathrm{Si}$ is easily accumulated in the interdendritic area as diffusion limitation. Consequently, the reaction for the formation of Fe-bearing phase occurs in the interdendritic region (Figure 11). There are several types of Fe-bearing intermetallic phases that can be formed in the solidification of aluminium alloy. The important intermetallics in cast alloys are the hexagonal $\alpha$-AlFeMnSi and the monoclinic $\beta$-AlFeSi [21]. The $\alpha$ $\mathrm{AlFeMnSi}$ is usually in a compact morphology with high symmetry crystal structure and the $\beta$-AlFeSi is characterised by a long needle shape with low symmetry crystal structure. Obviously, the $\alpha$-AlFeMnSi phase is preferable due to its less detrimental effect on the mechanical properties. The conventional metallurgical solutions to eliminate the formation of primary $\beta$-AlFeSi compounds include to limit the $\mathrm{Fe}$ content in the alloy, or to modify the crystal structures of $\beta$-AlFeSi compounds into $\alpha$-AlFeMnSi compounds by increasing $\mathrm{Mn} / \mathrm{Fe}$ ratio. However, higher amounts of $\mathrm{Mn}$ in aluminium melt lead to the formation of sludge in castings and increase the deleterious effect on their machinability [22, 23]. Therefore, the amount of Mn content should be controlled appropriately. Several formats have been reported for the $\alpha$-AlFeMnSi compounds. Zakharov et al. [24] found a stoichiometry of $\mathrm{Al}_{16}(\mathrm{Fe}, \mathrm{Mn}) \mathrm{Si}_{3}$ for the $\alpha$-AlFeMnSi phase in an alloy with 10 to $14 \mathrm{wt}-\% \mathrm{Si}, 0$ to $4 \mathrm{wt}-\%$ Fe and Mn. Devignon et al. [25] reported that the equilibrium compositions of the quaternary $\alpha$-AlFeMnSi phase can contain 72.7 to $74.7 \mathrm{at}-\%$ $\mathrm{Al}, 9.1$ to $13.7 \mathrm{at}-\% \mathrm{Fe}, 2.8$ to $5.7 \mathrm{at}-\% \mathrm{Mn}$, and 9.5 to $11.5 \mathrm{at}-\% \mathrm{Si}$, which exhibits the $\mathrm{Al}_{15}(\mathrm{Fe}, \mathrm{Mn})_{3} \mathrm{Si}_{2}$ stoichiometry. This is based on Fe substitution of the Mn sublattice sites of the $\mathrm{Al}_{15} \mathrm{Mn}_{3} \mathrm{Si}_{2}$ lattice, leading to idealised $\mathrm{Al}$ and $\mathrm{Si}$ contents of $75 \mathrm{at}-\%$ and $10 \mathrm{at}-\%$ respectively. According to the discussion by Fang et $a l$. [26], the stoichiometry of the quaternary $\alpha-\mathrm{AlFeMnSi}$ phase for Al-Si based alloys is best described by $\mathrm{Al}_{15}(\mathrm{Fe}, \mathrm{Mn})_{3} \mathrm{Si}_{2}$, with the crystal structure of the ternary $\alpha$-AlMnSi $\left(\mathrm{Al}_{15} \mathrm{Mn}_{3} \mathrm{Si}_{2}\right)$. In current study, the EDS analysis and morphology examination for the alloy confirms that the intermetallic phase is $\alpha$ - 
$\mathrm{AlFeMnSi}$. As there is limited literature on the detail of the intermetallic phase in $\mathrm{Al}$ alloys with high $\mathrm{Mg}$ content, it needs more investigations to reveal its origins. With regards to the measured $\mathrm{Mg}$ in the EDS results, it is doubtful that a measure error may exist because the size of $\alpha$-AlFeMnSi is too small in the sample which causes the reflection of back materials in the EDS measurement. It needs to be clarified that one may think the Fe-bearing phase is formed in the shot sleeve or even before the formation of primary $\alpha$ Al phase. If this is true, the intermetallic phase should form a large grain size and/or dendritic morphology because of the relatively low cooling rate in the shot sleeve. The size, morphology and the distribution of intermetallics suggest that it is formed in the die cavity prior to the eutectic solidification.

The eutectic solidification forms fine eutectic cells with lamellar morphology of $\mathrm{Mg}_{2} \mathrm{Si}$ phase and $\alpha-\mathrm{Al}$ phase. The high cooling rate results in the formation of fine eutectic cells that are distributed uniformly in the matrix (Figure 11). The separated eutectic cells are beneficial for the mechanical properties of diecast alloy, especially for ductility.

\subsection{Microstructure-properties relationship}

The Al-Mg-Si alloy developed in this work has shown the improved mechanical properties, in particular, the improved ductility. Although it is usually believed the mechanical property, especially the ductility of die castings, is mainly determined by their defect levels; the microstructure is still a critical factor. The microstructure in the die castings compromises the primary $\alpha$-Al phase, the intermetallic phase and the eutectics. The primary $\alpha-\mathrm{Al}$ phase is fine with solution strengthening of $\mathrm{Mg}, \mathrm{Si}$ and $\mathrm{Mn}$. The fine primary phase can uniform the stress distribution and therefore improve the mechanical properties. The elongation is also largely dependent on the morphologies and sizes of the intermetallic compounds. The compact $\alpha-$ $\mathrm{AlFeMnSi}$ phase can reduce the detrimental effect of needle intermetallics. The tiny particle may act as a pin to prevent grain boundary sliding during loading. Because of the tight control of other impurities in the alloy, very limited other intermetallics can be formed during solidification and their detrimental effects are significantly diminished. The distribution of fine $\mathrm{Mg}_{2} \mathrm{Si}$ in the eutectic cells is also beneficial for the mechanical properties.

In order to achieve the consistent mechanical properties, the other aspects including the gas content in the melt and the porosity level in the castings are equally important with the microstructure. The control of gas content in the alloy can be achieved consistently by proper control of the degassing process. The porosity level in the die castings will vary case by case and significantly depend on the structure of castings. For castings used in car body structure, thin wall thickness and a large project area are two main features. The fluid flow is usually long and therefore the gating system is one of the critical issues to reduce the defects level.

\section{Conclusions}

(1) The super ductile diecast aluminium alloys for automotive body structure have been developed. The optimized composition comprises of $5-5.5 \mathrm{wt}-\% \mathrm{Mg}, 1.5-2.0 \mathrm{wt}-\mathrm{Si} \%, 0.5-0.7 \mathrm{wt}-\% \mathrm{Mn}, 0.15-0.2 \mathrm{wt}-\% \mathrm{Ti}$. The other impurity elements should be limited in the alloy; especially Fe should be controlled less than $0.25 \mathrm{wt}-\%$. The typical mechanical properties of the diecast alloy at optimized composition are $150 \mathrm{MPa}$ of yield strength, $300 \mathrm{MPa}$ of ultimate tensile strength, and $15 \%$ of elongation under as-cast condition.

(2) The paint baking hardenability of the alloy is insignificant. The increase of the yield strength of the diecast alloy is less than $10 \%$ after a simulated ageing under $180^{\circ} \mathrm{C}$ for $30 \mathrm{~min}$.

(3) $\mathrm{Cu}$ can slightly increase the yield strength under as-cast condition or under heat treated condition with significant scarifying the ductility. Therefore, $\mathrm{Cu}$ should be limited in the super ductile aluminium alloy.

(4) The microstructure of diecast aluminium alloys at an optimized composition consists of the primary $\alpha$ $\mathrm{Al}$ phase, the $\alpha$-AlFeMnSi phase and the eutectics. There are two types of $\alpha$-Al phase; dendrites or fragmented dendrites solidified in the shot sleeve and globular particles solidified in the die cavity. The $\alpha$-AlFeMnSi phase is in the form of compact morphology and smaller than $3 \mu \mathrm{m}$ in size. The eutectic cells are about $10 \mu \mathrm{m}$ in size with a lamellar morphology of $\alpha$-Al phase and $\mathrm{Mg}_{2} \mathrm{Si}$ phase.

\section{Acknowledgements}

This project is financially supported by EPSRC and JLR UK. The assistance for the SEM analysis from Dr. Yun Wang is gratefully appreciated. 
Table. 1. The mechanical properties of aluminium wrought alloys used for automotive body structure [8,9].

\begin{tabular}{|c|c|c|c|c|c|}
\hline \multirow[b]{2}{*}{ Alloy-Temper } & \multicolumn{3}{|c|}{ As-received } & \multicolumn{2}{|r|}{ After Paint Baking } \\
\hline & $\begin{array}{l}\text { Yield Strength } \\
(\mathrm{MPa})\end{array}$ & $\begin{array}{l}\text { Ultimate } \\
\text { Strength } \\
(\mathrm{MPa})\end{array}$ & $\begin{array}{l}\text { Total } \\
\text { Elongation } \\
(\%)\end{array}$ & $\begin{array}{l}\text { Uniform } \\
\text { Elongation } \\
(\%) \\
\end{array}$ & $\begin{array}{l}\text { Yield Strength } \\
(\mathrm{MPa})\end{array}$ \\
\hline $5030-\mathrm{T} 4$ & 138 & 276 & 30.0 & - & 172 \\
\hline $5754-\mathrm{H} 22$ & 185 & 245 & 15 & - & - \\
\hline $5754-\mathrm{H} 26$ & 245 & 290 & 10 & - & - \\
\hline 6009-T4 & 124 & 221 & 25.0 & 21.0 & 234 \\
\hline 6010-T4 & 172 & 290 & 24.0 & 21.0 & 255 \\
\hline 6013-T4 & 186 & 317 & 25.0 & 23.3 & 324 \\
\hline 6016-T4 & 139 & 248 & 29.0 & 21.5 & 221 \\
\hline 6063-Т6 & 214 & 241 & 18.0 & - & - \\
\hline 6082-T6 & 250 & 290 & 10.0 & - & - \\
\hline 6111-T4 & 159 & 290 & 27.5 & 22.0 & 261 \\
\hline
\end{tabular}

Table 2. Typical mechanical properties of aluminium diecast alloys commonly available in industry.

\begin{tabular}{llllllll}
\hline & & \multicolumn{2}{l}{$\begin{array}{l}\text { Ultimate Tensile } \\
\text { Main alloying }\end{array}$} & \multicolumn{2}{l}{$\begin{array}{l}\text { Yield Strength } \\
\text { Strength (MPa) }\end{array}$} & \multicolumn{2}{l}{$\begin{array}{l}\text { Elongation } \\
\text { in 50mm }(\%)\end{array}$} \\
\cline { 3 - 7 } Alloy & elements & Ref. [10] & Ref. [11] & Ref. [10] & Ref. [11] & Ref. [10] & Ref. [11] \\
\hline 360 & Al-Si & 300 & 324 & 170 & 172 & $2 \cdot 5$ & 3 \\
A360.0 & Al-Si & 320 & 317 & 170 & 165 & 3.5 & 5 \\
364 & Al-Si & - & 296 & - & 159 & - & 7.5 \\
380 & Al-Si-Cu & 320 & 331 & 160 & 165 & 2.5 & 3 \\
A380.0 & Al-Si-Cu & 320 & 324 & 160 & 159 & $3 \cdot 5$ & 4 \\
383 & Al-Si-Cu & 310 & - & 150 & - & 3.5 & - \\
384 & Al-Si-Cu & 330 & 324 & 170 & 172 & 2.5 & 1 \\
390 & Al-Si-Cu-Mg & 280 & 279 & 240 & 241 & $<1$ & 1 \\
8390 & Al-Si-Cu-Mg & 320 & - & 250 & - & $<1$ & - \\
392 & Al-Si-Mg-Cu & 290 & 290 & 270 & 262 & $<1$ & $<0.5$ \\
413 & Al-Si & 300 & 296 & 140 & 145 & 2.5 & 2.5 \\
A413.0 & Al-Si & 290 & 241 & 130 & 110 & 3.5 & 3.5 \\
443 & Al-Si-Cu & - & 228 & - & 110 & - & 9 \\
513 & Al-Mg-Zn & - & 276 & - & 152 & - & 10 \\
516 & Al-Mg-Si & - & 283 & - & - & - & 10 \\
518 & Al-Mg & 310 & 310 & 190 & 186 & 5 & 8 \\
\hline
\end{tabular}

Table 3. The composition of diecast Al-Mg-Si alloy designed in different countries.

\begin{tabular}{|c|c|c|c|c|c|c|c|c|c|c|}
\hline Country & Alloy & $\mathrm{Si}$ & $\mathrm{Mg}$ & $\mathrm{Fe}$ & $\mathrm{Cu}$ & $\mathrm{Mn}$ & $\mathrm{Zn}$ & $\mathrm{Ti}$ & Others & $\mathrm{Al}$ \\
\hline UK (BS1490) & LM5 & 0.3 & $3.0-6.0$ & 0.8 & 0.1 & $0.3-0.7$ & 0.1 & 0.05 & $\mathrm{Ni0.3,} \mathrm{Pb0.1}$ & Bal. \\
\hline China (GB/15115) & YL302 & $0.8-1.3$ & $4.5-5.5$ & $\leq 1.2$ & $\leq 0.1$ & $0.1-0.4$ & $\leq 0.2$ & $\leq 0.2$ & - & Bal. \\
\hline Germany (DIN) & $\begin{array}{l}\text { GK- } \\
\text { AlMg5Si }\end{array}$ & $0.9-1.5$ & $4.8-5.5$ & 0.4 & 0.03 & $\leq 0.4$ & 0.1 & 0.001 & - & Bal. \\
\hline $\begin{array}{l}\text { France (NFA57- } \\
105)\end{array}$ & AG66 & 0.4 & $5.0-7.0$ & 0.5 & 0.1 & 0.5 & 0.2 & 0.2 & $\begin{array}{l}\mathrm{Ni0} 05, \mathrm{~Pb} 0.05, \\
\text { Sn0.05 }\end{array}$ & Bal. \\
\hline $\begin{array}{l}\text { Russia (ГOGT } \\
2685)\end{array}$ & АМг $4 \mathrm{~K} 1$ & $1.3-1.7$ & $4.5-5.2$ & 0.4 & $0.7-1$ & $0.6-0.9$ & - & $0.1-0.25$ & Be 0.003 & Bal. \\
\hline Japan (JIS H2212) & ADC6 & $\leq 1.0$ & $2.6-4.0$ & $\leq 0.6$ & $\leq 0.1$ & $0.4-0.6$ & $\leq 0.4$ & & $\mathrm{Ni} \leq 0.1, \mathrm{Sn} \leq 0.1$ & Bal. \\
\hline USA (ASTM B179) & 516.0 & $0.3-1.5$ & $2.5-4.5$ & $0.35-1.0$ & 0.3 & $0.15-0.4$ & 0.2 & $0.1-0.2$ & $\mathrm{Ni0.25-0.4}$ & Bal. \\
\hline Sweden & 4163 & $0.5-1.5$ & $4.0-6.0$ & 0.5 & 0.1 & 0.5 & 0.2 & 0.2 & $\begin{array}{l}\text { Ni0.05,Pb0.05, } \\
\text { Sn0.05 }\end{array}$ & Bal. \\
\hline
\end{tabular}




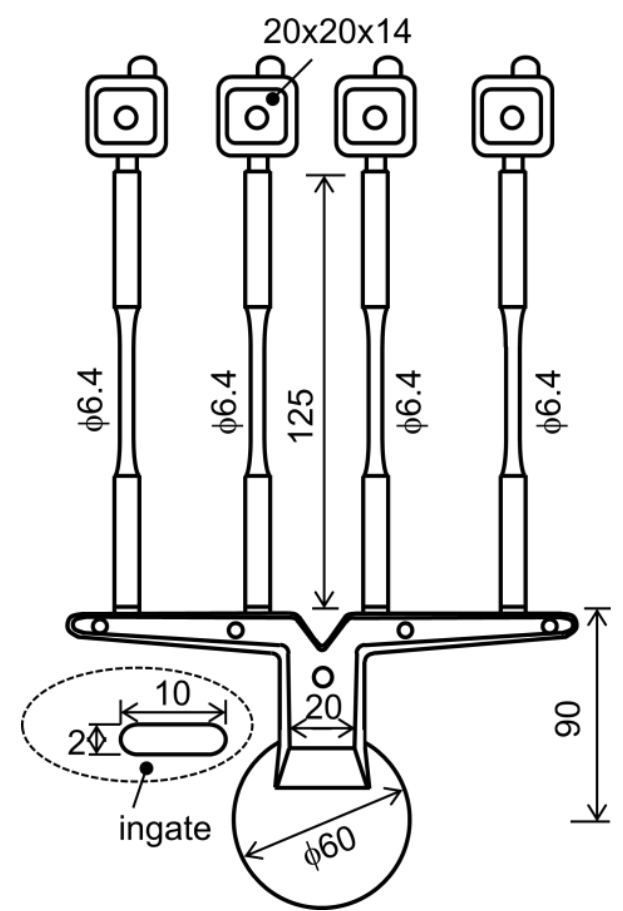

Figure 1. Diagram of die castings for standard tension testing cast aluminium alloy according to the specification defined in ASTM B557-06. The overflow and biscuit are designed in associated with cold chamber die casting machine. The dimensions are in $\mathrm{mm}$.
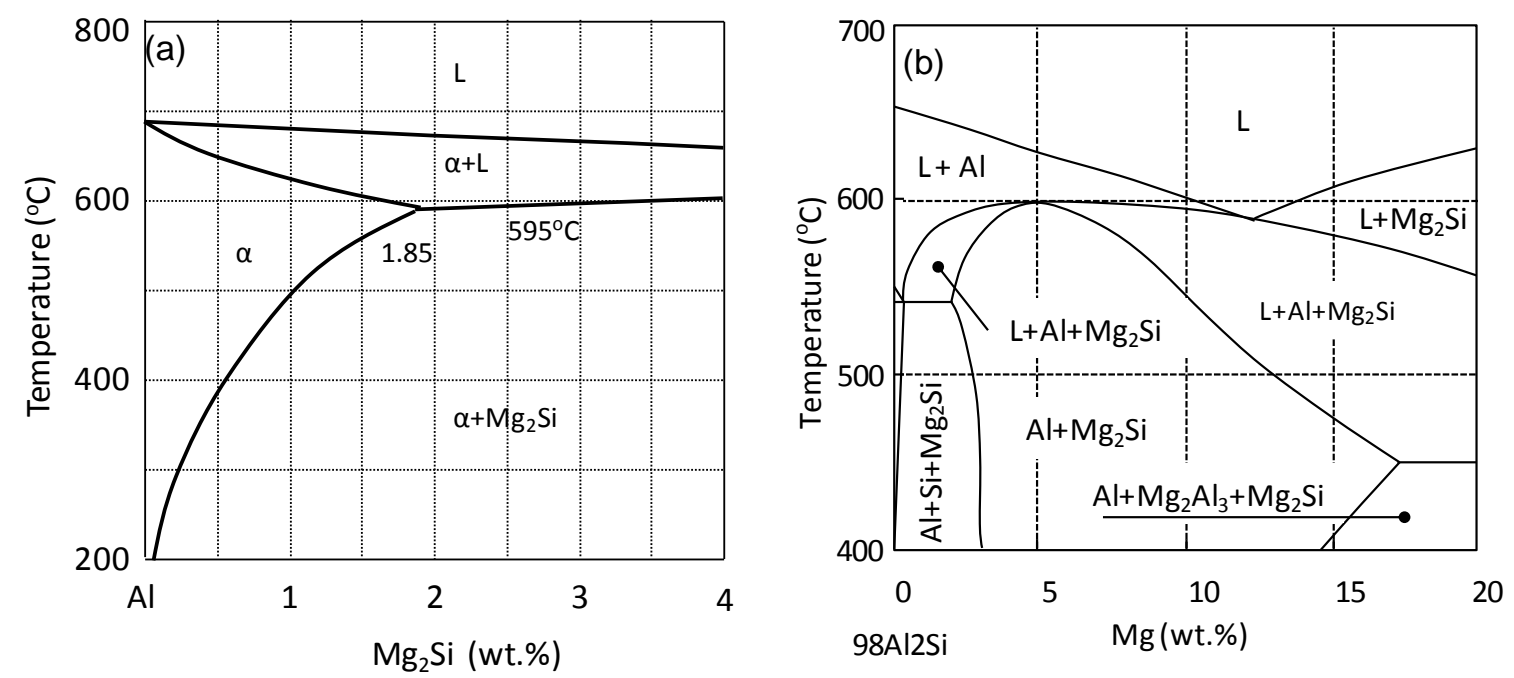

Figure 2. The equilibrium phase diagrams (a) Al- $\mathrm{Mg}_{2} \mathrm{Si}$ binary alloy [17], (b) Al-Mg-Si ternary alloy [18]. 

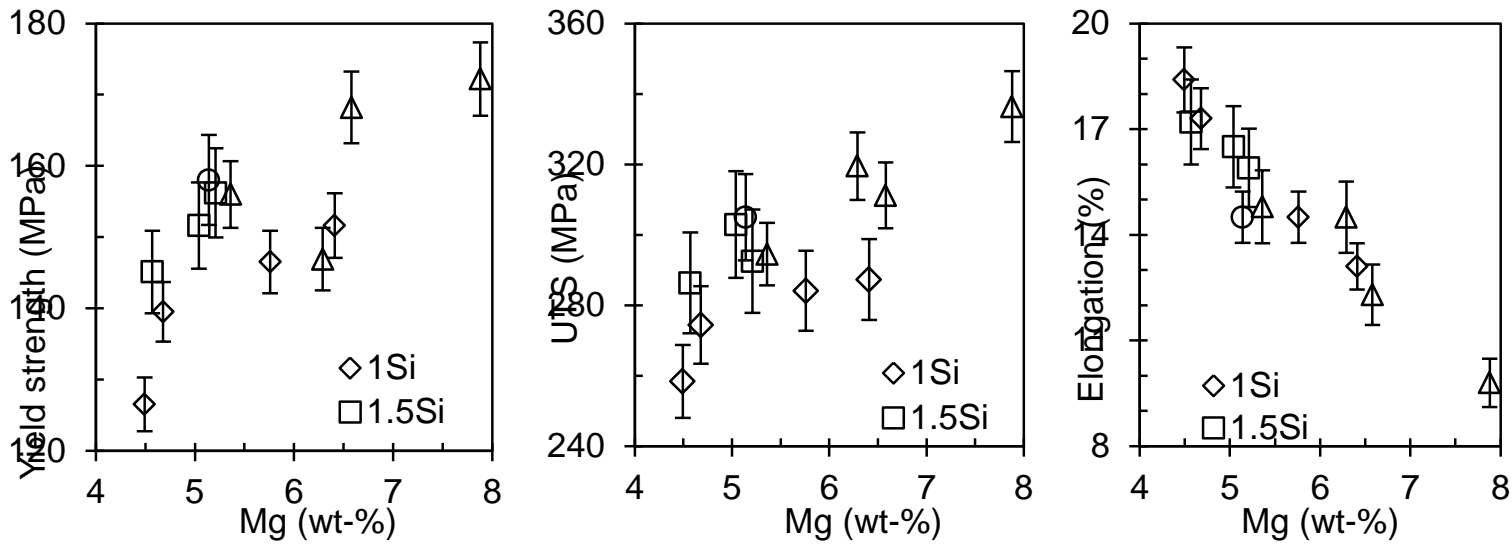

Figure 3. Effect of Mg and Si on (a) the yield strength, (b) the ultimate tensile strength (UTS) and (c) the elongation of the Al-Mg-Si diecast alloy in as-cast state. The other elements in the alloys include 0.6wt$\% \mathrm{Mn}, 0.2 \mathrm{wt}-\% \mathrm{Ti}$ and $0.25 \mathrm{wt}-\% \mathrm{Fe}$.

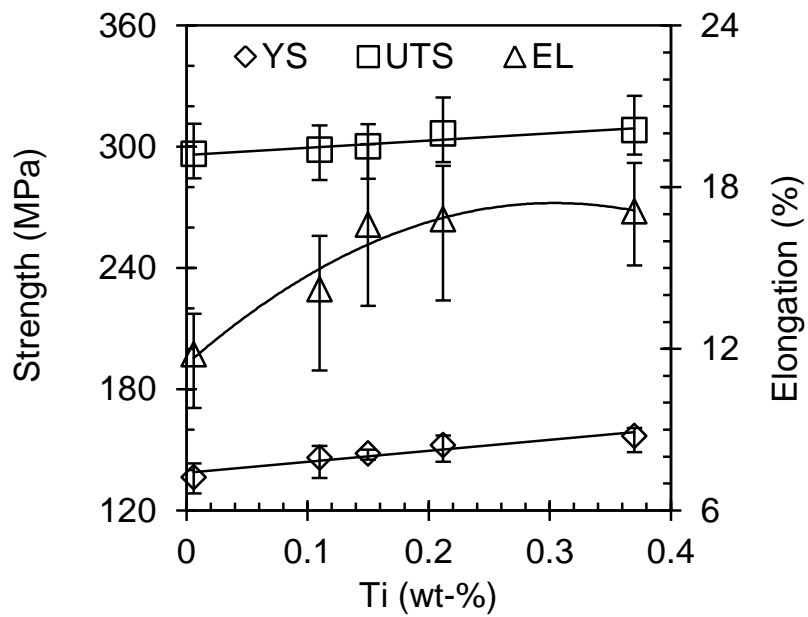

Figure 4. Effect of Ti on the yield strength (YS), the ultimate tensile strength (UTS) and the elongation (EL) of the Al-Mg-Si diecast alloy in as-cast state. The other elements in the alloys include $5 \mathrm{wt}-\% \mathrm{Mg}$, $1.5 \mathrm{wt}-\% \mathrm{Si}, 0.6 \mathrm{wt}-\% \mathrm{Mn}$ and $0.25 \mathrm{wt}-\% \mathrm{Fe}$.

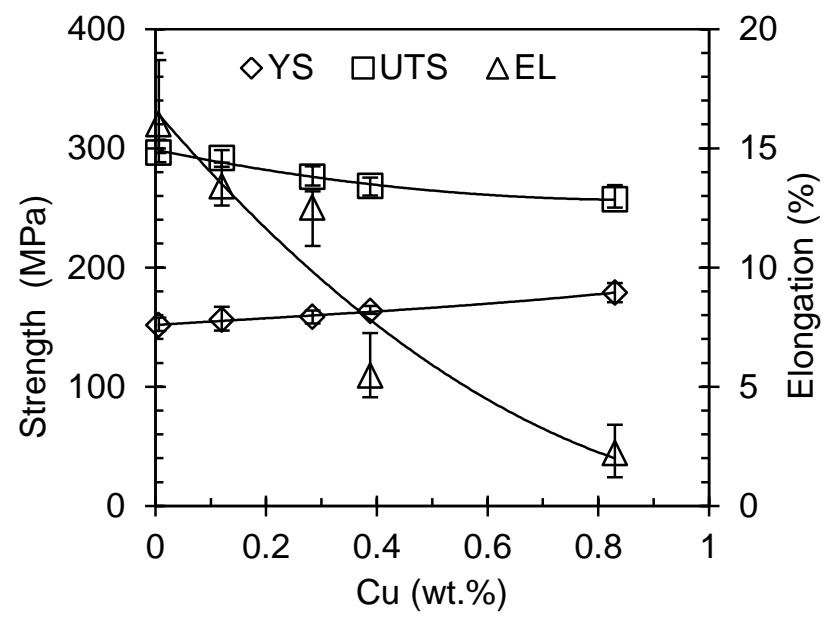

Figure 5. Effect of $\mathrm{Cu}$ on the yield strength (YS), the ultimate tensile strength (UTS) and the elongation (EL) of the Al-Mg-Si diecast alloy in as-cast state. The other elements in the alloys include $5 \mathrm{wt}-\% \mathrm{Mg}$, $1.5 \mathrm{wt}-\% \mathrm{Si}, 0.6 \mathrm{wt}-\% \mathrm{Mn}, 0.2 \mathrm{wt}-\% \mathrm{Ti}$ and $0.25 \mathrm{wt}-\% \mathrm{Fe}$. 


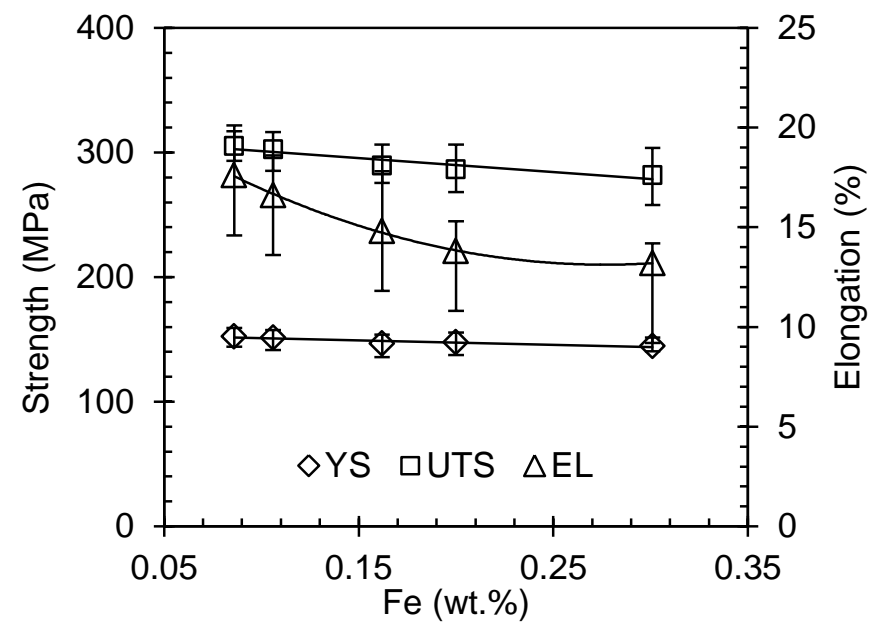

Figure 6. Effect of Fe on the yield strength (YS), the ultimate tensile strength (UTS) and the elongation (EL) of the Al-Mg-Si diecast alloy in as-cast state. The other elements in the alloys include $5 \mathrm{wt}-\% \mathrm{Mg}$, $1.5 \mathrm{wt}-\% \mathrm{Si}, 0.6 \mathrm{wt}-\% \mathrm{Mn}, 0.2 \mathrm{wt}-\% \mathrm{Ti}$.

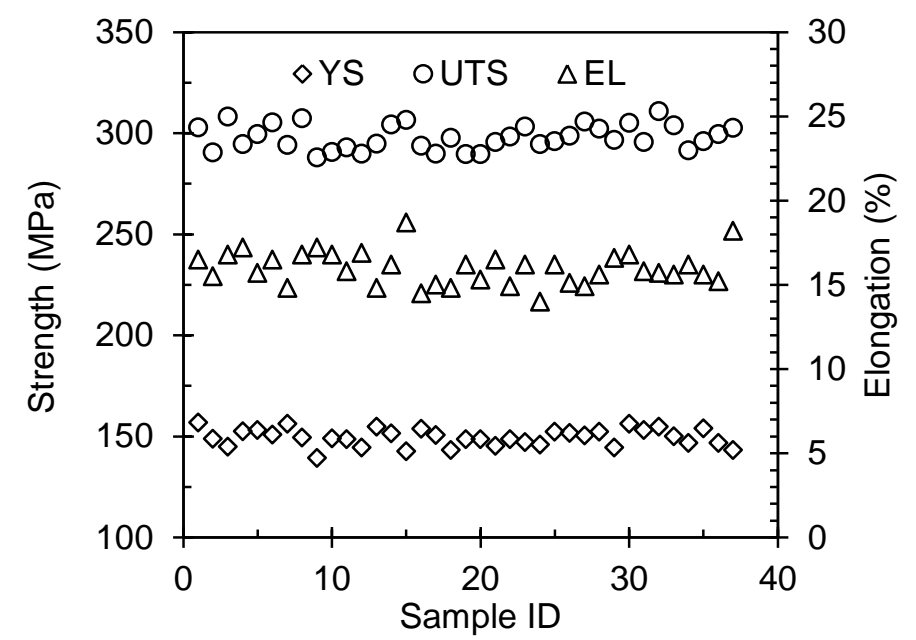

Figure 7. The yield strength (YS), the ultimate tensile strength (UTS) and the elongation (EL) of the optimized Al-Mg-Si diecast alloy in as-cast state. The other elements in the alloys include $5 \mathrm{wt}-\% \mathrm{Mg}$, $1.5 \mathrm{wt}-\% \mathrm{Si}, 0.6 \mathrm{wt}-\% \mathrm{Mn}, 0.2 \mathrm{wt}-\% \mathrm{Ti}$ and $0.25 \mathrm{wt}-\% \mathrm{Fe}$.

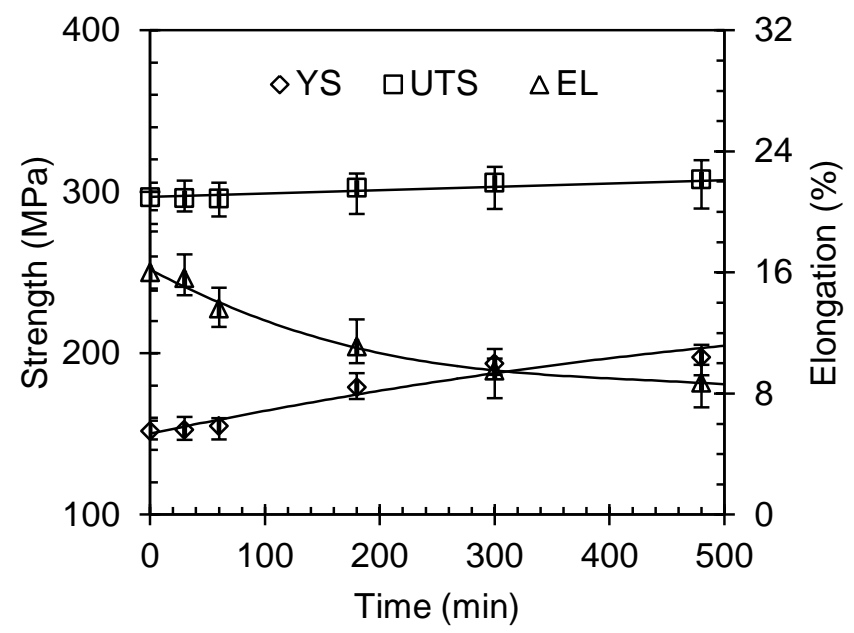

Figure 8. Effect of ageing time at $180^{\circ} \mathrm{C}$ on the yield strength (YS), the ultimate tensile strength (UTS) and the elongation (EL) of the Al-Mg-Si diecast alloy. The other elements in the alloys include $5 \mathrm{wt}-\% \mathrm{Mg}$, $1.5 \mathrm{wt}-\% \mathrm{Si}, 0.6 \mathrm{wt}-\% \mathrm{Mn}, 0.2 \mathrm{wt}-\% \mathrm{Ti}$ and $0.25 \mathrm{wt}-\% \mathrm{Fe}$. 

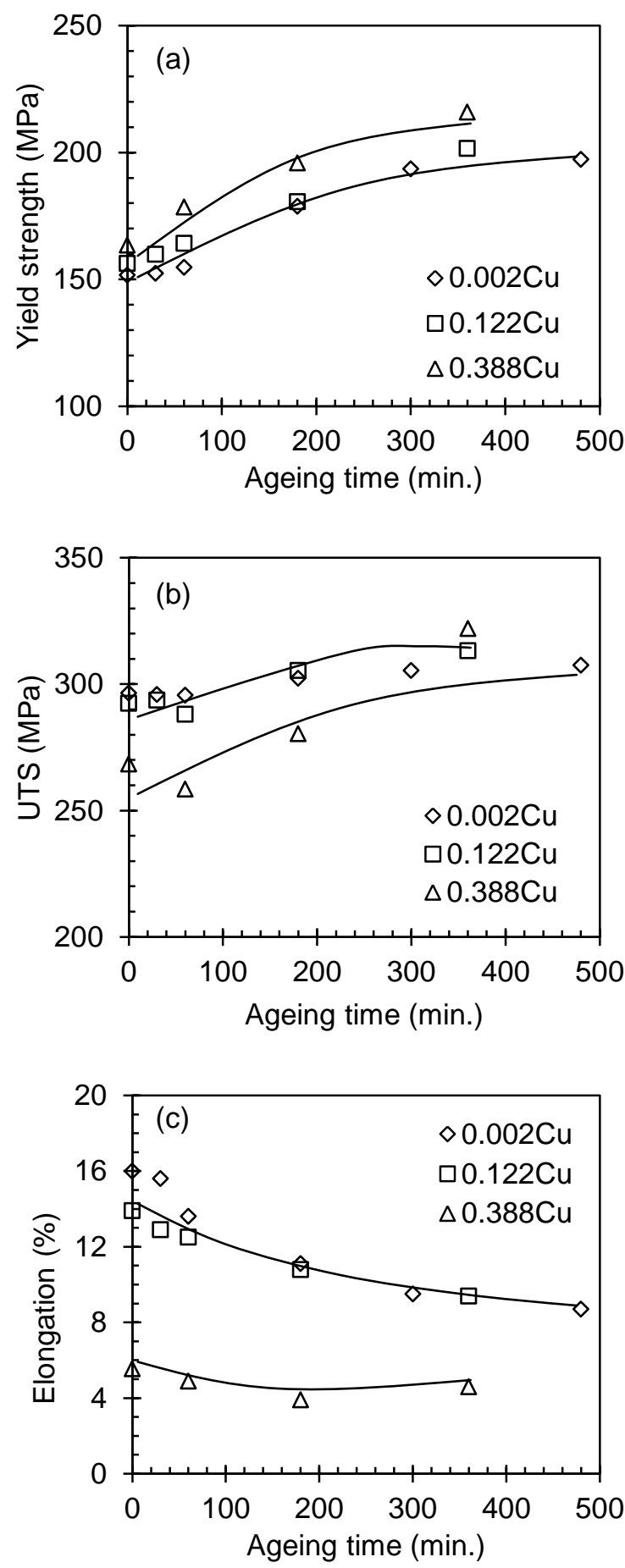

Figure 9. Effect of $\mathrm{Cu}$ content on the yield strength (YS), the ultimate tensile strength (UTS) and the elongation (EL) of the Al-Mg-Si diecast alloy aged at $180^{\circ} \mathrm{C}$. The other elements in the alloys include $5 \mathrm{wt}-$ $\% \mathrm{Mg}, 1.5 \mathrm{wt}-\% \mathrm{Si}, 0.6 \mathrm{wt}-\% \mathrm{Mn}, 0.2 \mathrm{wt}-\% \mathrm{Ti}$ and $0.25 \mathrm{wt}-\% \mathrm{Fe}$. 

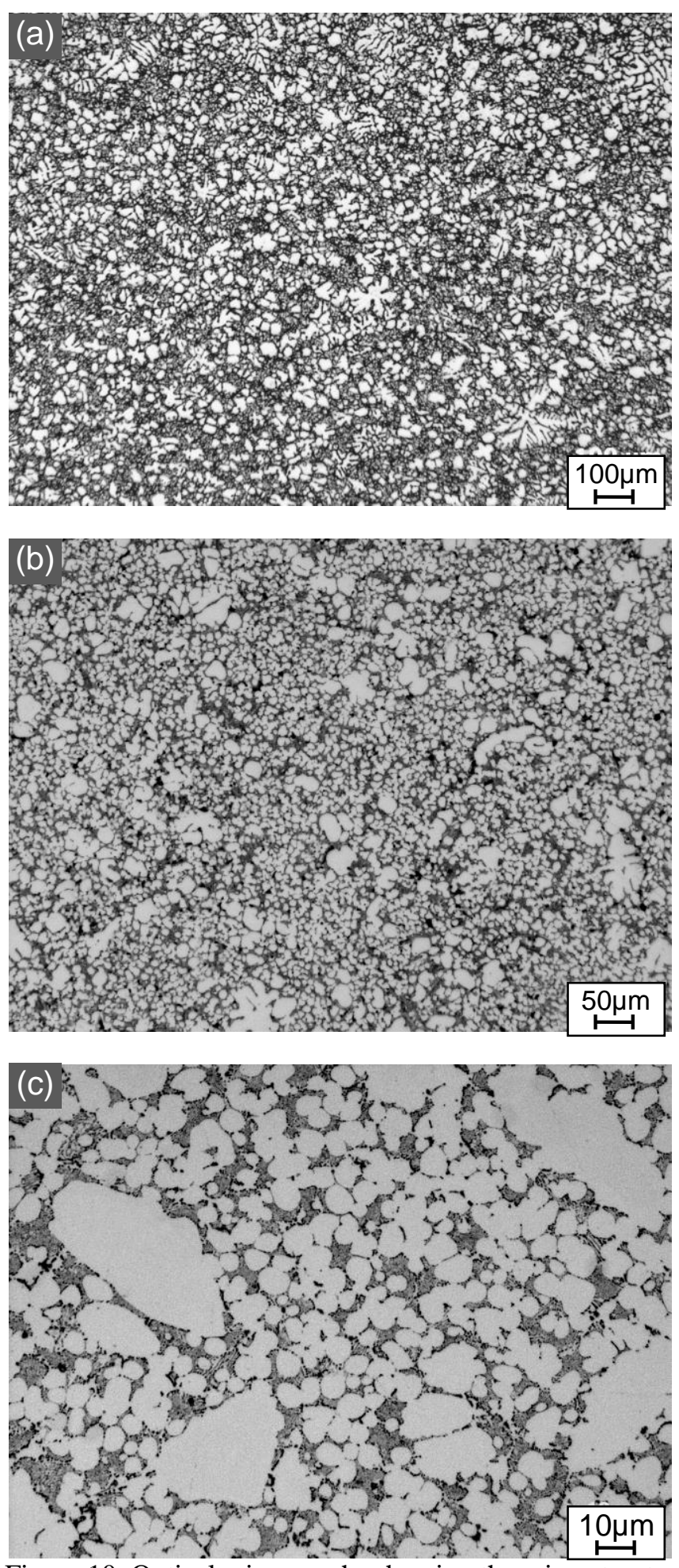

Figure 10. Optical micrographs showing the microstructures of the Al-Mg-Si diecast alloy with a primary $\alpha$-Al phase at $\mathrm{f}_{\mathrm{s}}=19 \%$, (a) overall image showing the distribution of primary $\alpha$-Al phase with dendrites or fragmented dendrites morphology, (b) image showing the primary $\alpha$-Al phase with fragmented dendrites morphology, (c) image showing the primary $\alpha$-Al phase with globular morphology. 

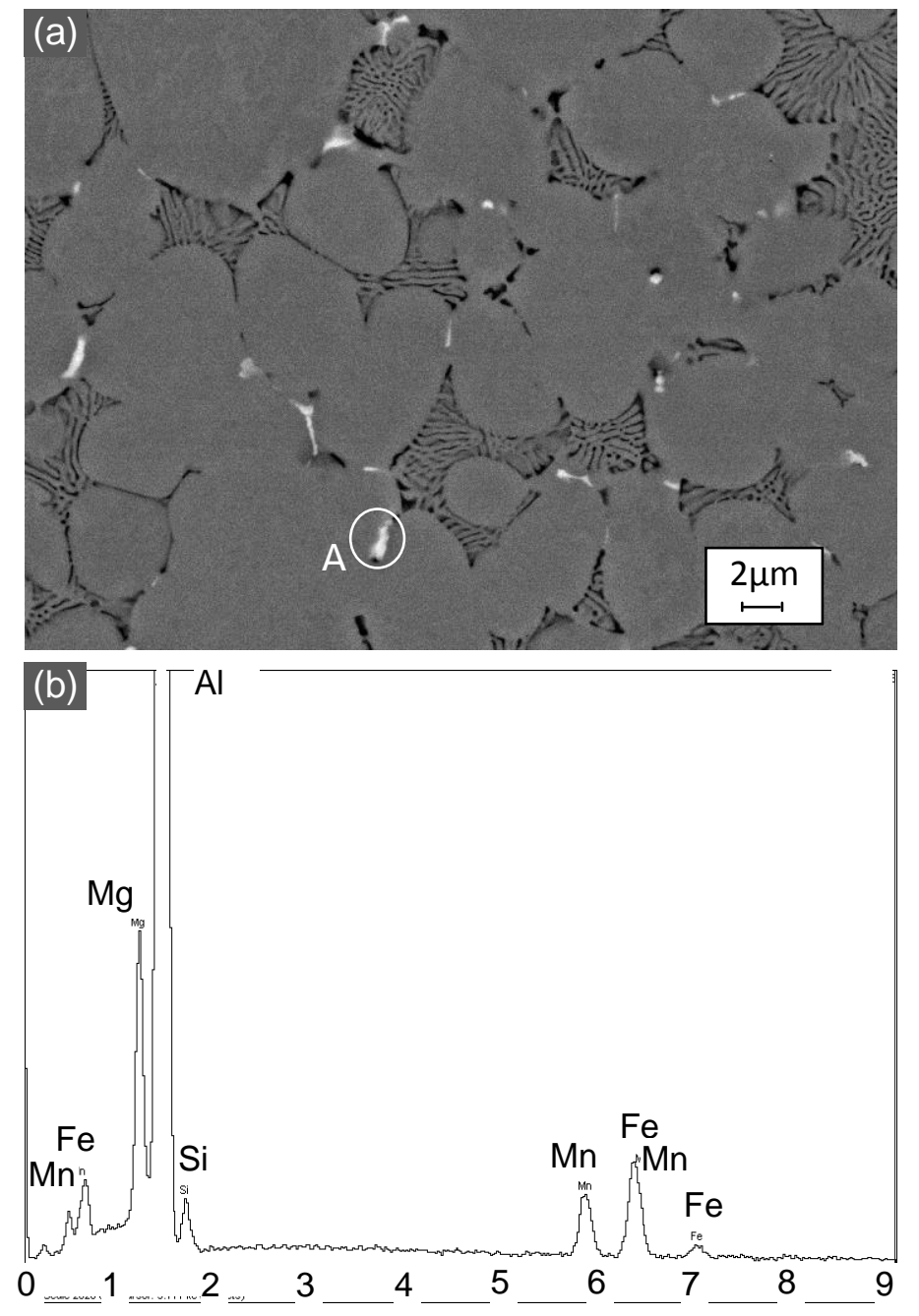

Figure 11. (a) Backscattered SEM micrograph showing the distribution of intermetallics along grain boundaries in the Al-Mg-Si diecast alloy, and (b) EDS diagram showing the elements in particle A. 

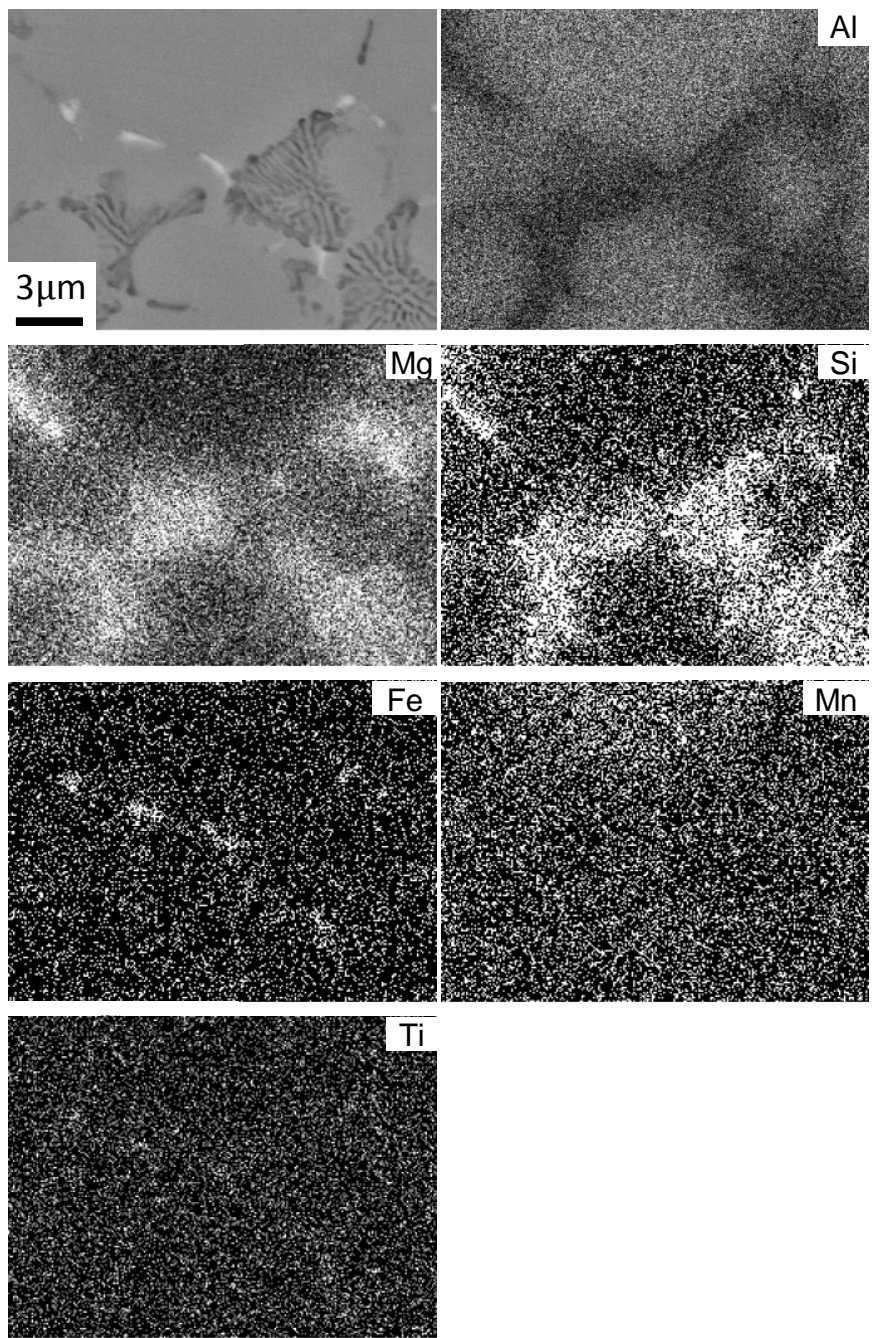

$9 \mu \mathrm{m}$

Figure 12. Backscattered SEM micrograph and the series of elemental maps showing the distribution of key elements in Al-Mg-Si diecast alloy. Map conditions: $20 \mathrm{kV}, 185 \mathrm{nA}, 5 \mathrm{~nm}$ step size and a counting time of $15 \mathrm{~ms}$ per step.

\section{Reference}

[1] A.I. Taub, P.E. Krajewski, A.A. Luo, J.N.Owens, JOM 2(2007)48-57.

[2] D. Codd, Advanced Lightweight Materials Development and Technology for Increasing Vehicle Efficiency, KVA Inc., Escondido CA 92029 USA, 2008.

[3] T. Zeuner, L. Würker, Process Optimisation of Cast Aluminium Chassis Components WFO Technical Forum 2003, p3.1-3.14.

[4] A.Tharumarajah, Resources Conservation and Recycling 52 (2008) 1185-89.

[5] W.S. Miller, L. Zhuang, J. Bottema, A.J. Wittebrood, P. DeSmet, A. Haszler, A. Vieregge, Mater Sci Eng A 280 (2000)37-49.

[6] European Aluminium Association. Aluminium in cars. European Aluminium Association, 2008

[7] The Aluminium Association, Inc., Aluminium: The Corrosion Resistant Automotive Material, Publication AT7, May, 2001.

[8] J.T. Staley, D.J. Lege, J. De Physique IV 3(1993)179-190.

[9] S. Ji, Light-weighted Materials for Automotive Industry, BCAST Internal Report, Brunel University, UK, 2011.

[10] Annual Book of ASTM standards, vol. 02.02, Warrendale PA, ASTM, 1993. 
[11] D. M. Stefanscu, J. R. Davis, J.D. Destefani (eds.), ASM metals handbook, 9th edn, vol. 15, Casting, Metals Park, OH, ASM International, 1988.

[12] M. Rettenmayr, Int. J. Mat. Res. 100(2009) 153-59.

[13] V.S. Zolotorevsky, N.A. Belov, M.V. Glazoff, Casting Aluminium, ISBN 9780080453705, Elsevier, 2007, p 484.

[14] R-Z. Tian, Cast Aluminium Alloys, Mid-Southern University Press, 1st ed., 2006 (in Chinese).

[15] H. Koch, B. Lenczowski, Al/Mg/Si Cast Aluminium Containing Scandium, WO/2005/047554, 2005.

[16] G. Trenda, A. Kraly, Aluminium Alloy, WO/2006/122341, 2006

[17] G.E. Tot, D.S. MacKenzie, Handbook of Aluminium vol.7 Physical Metallurgy and Processes, Marcel Dekker, Inc. New York, Basel, ISBN 0-8247-0494-0, 1st ed., 2003.

[18] V. Raghavan, J. Phase Equilibria and Diffusion, 28(2007)189-91.

[19] J.A. Taylor, Cast Metals, 8(1995)225-252.

[20] R. Ahmad, R. Marshall, Inter. J. Cast Metal Res. 15(2003)497-504.

[21] P. Villars, L.D. Calvert (eds.), Pearson's Handbook of Crystallographic Data for Intermetallic Phases, 2nd ed., Materials Park, OH, ASM International, 1991.

[22] G. Gustafsson, J. Thorvaldsson, G. L. Dunlop, Metall. Mater. Trans. A, 17A(1986)45-52.

[23] S. Murali, K.S. Raman, K.S.S. Murthy, Mater. Sci. Eng. A, 190A(1995)165-72.

[24] A.M. Zakharov, I.T. Guldin, A.A.Aenold, A. Yu, Matsenko. Izv. Akad. Nauk SSSR Metall. 4 (1989) 21423.

[25] G. Davignon, A. Serneels, B. Verlinden, L. Delaey, Metall. Mater. Trans. A 27A (1996) 3357-61.

[26] X. Fang, G. Shao, Y.Q. Liu, Z. Fan, Mater. Sci. Eng. A, 445-446 (2007) 65-72. 